Agnieszka Kwiatkowska

„I razem sobie zmyślamy różne bajeczki i bzdurki”. Lingwizm w poezji Danuty Wawiłow ${ }^{1}$

W drugiej połowie lat 5o. ubiegłego wieku, po trudnych czasach realizmu socjalistycznego, sytuacja poezji polskiej uległa radykalnej odmianie. Otworzyły się nowe możliwości dla twórców awangardowych, racjonaliści rywalizowali z poetami wyzwolonej wyobraźni, poszukiwano nowych sposobów wyrażenia prawdy o kondycji człowieka, uciekając się do strategii pacjenta, gloryfikowania brzydoty czy zabiegów lingwistycznych. Rozwój językoznawstwa - zwłaszcza świadomość, że język nie jest biernym narzędziem komunikacji, ale wywiera wpływ na obraz świata - sprzyjał ożywieniu liryki słowiarskiej, sięgającej do tradycji Awangardy Krakowskiej. Zwrot ku językowi dawał możliwości przekroczenia zaangażowania ideologicznego i wypracowania przestrzeni wolnej od politycznego dyskursu. Jednym z naczelnych zadań nowej poezji stała się walka ze złudzeniem, że mowa postrzegana jako nienacechowane światopoglądowo narzędzie komunikacji jest

1 Artykuł powstał w ramach realizacji grantu Stulecie Poetek Polskich UMO-2015/17/B/HS2/01245. Cytat w tytule artykułu pochodzi z wiersza Danuty Wawilow Spacerek [Wawilow 1993: 23]. 
bezgranicznie posłuszna intencjom użytkownika [por. Balcerzan 1998: 189]. Oddziaływanie przełomu lingwistycznego - niezwykle wyraziste w poezji pokolenia „Współczesności” - nie słabło w kolejnych dekadach, kształtując między innymi poetykę Nowej Fali. Z lingwizmem wiązał się też wzrost zainteresowania językiem dziecka, które w konsekwencji niepełnej znajomości reguł w naturalny sposób miało do nich twórczy stosunek.

Obiektem zainteresowania, niejako materią poezji lingwistycznej, zarówno tej uniwersalnej, jak i adresowanej do dzieci, są - jak zaznaczał Antoni Smuszkiewicz - „skostniałe związki frazeologiczne, szablony stylistyczne, gry słowne oraz czysto brzmieniowe powinowactwa wyrazów, dające komiczne efekty [...]. Słowo przestaje być tylko tworzywem literackim, a staje się tematem poezji, eksponującej swą autoteliczność” [Smuszkiewicz 2015: 149]. W wierszach dla dzieci lingwizm nie dąży do budowania nieufności wobec języka, nie podważa wiary w sprawność komunikacji. Służy raczej sprawdzeniu możliwości, pozwala wypróbować różne zwroty, połączenia wyrazów, współbrzmienia, dostrzec względność relacji między słowem a jego znaczeniem. Korniej Czukowskij zwracał uwagę, że w pewnym wieku - zgodnie z tytułem jego dzieła $\mathrm{Od}$ dwóch do pięciu - każde dziecko staje się lingwistą, eksperymentatorem badającym sposoby używania języka i radującym się współbrzmieniem, nawet asemantycznym [por. Czukowskij 1962: 177-178]. Jerzy Cieślikowski pisał:

Dziecko nie zadowala się istniejącym zasobem słownikowym, ale postępuje z nim w sposób bezceremonialny, tworząc słowa zupełnie nowe lub nie znając struktury gramatycznej tworzy słowa na zasadzie analogii fleksyjnej czy wreszcie przenosi znane słowa $\mathrm{z}$ jednych kontekstów znaczeniowych w inne. [Cieślikowski 1967: 229]

Poznawczy stosunek do świata objawia się zamiłowaniem do wywracanek (to określenie Cieślikowskiego [por. 1967: 236]), w których - w literaturze czy na ilustracji - jawi się świat na opak, nieustannie sprawdzany i weryfikowany w dziecięcej wyobraźni. Absurd oraz groteska stają się naturalnym następstwem takiego 
postrzegania i używania języka, łącząc dziecięcą poezję lingwistyczną z tradycją literatury sowizdrzalskiej i kreacji świata au rebours.

Jako konsekwencja zaskakujących zabaw z językiem z utrwalonych szablonów codziennej mowy dorosłych (np. „być głową domu”, „robić swetry na drutach”, „wziąć kogoś na barana”) wyłania się w tych utworach - pisze Smuszkiewicz - absurdalny, groteskowy świat, bliski sposobowi myślenia i fantazjowania dziecka. Ponadto absurdalny dowcip wierszy często uwypukla satyryczne akcenty, które co prawda nie zawsze są dla każdego dziecka czytelne, ale znajdują uznanie u dorosłego pośrednika lektury, bo do niego są przede wszystkim adresowane. [Smuszkiewicz 2015: 149-150]

Granica między poezją dla dzieci a poezją dziecięcą, według rozróżnienia Cieślikowskiego, w przypadku twórczości lingwistycznej zaciera się, a czasami nawet zostaje zniesiona. Wyraziście zaznacza się to w tekstach Jana Brzechwy. Droga autora Kaczki dziwaczki „od modernizmu do lingwizmu”, jak zwięźle określiła ją Anna Szóstak [2003: 5], to w gruncie rzeczy pasaż od liryki pod znakiem Bolesława Leśmiana czy Skamandra ku twórczości dla dzieci, w której lingwizm Brzechwy objawił się najpełniej i wyjątkowo barwnie, łącząc się z absurdalnym dowcipem. Poeta w tekstach dla dzieci sięgał po podobne chwyty jak Tymoteusz Karpowicz czy Miron Białoszewski, ale w niedoskonałościach języka, w jego niezamierzonych polisemiach czy braku precyzji, widział raczej szansę rozwoju i źródło kreatywnej gry niż zagrożenie dla komunikacji.

Twórczość Danuty Wawiłow wpisuje się w tradycję poezji lingwistycznej, ale realizuje jej zupełnie inną odmianę. Pisarka związana z pokoleniem „Współczesności” debiutowała na początku lat 60., pierwszy tomik wierszy dla dzieci wydała jednak dopiero w 1977 roku [por. Mucha 2005: 23]. W jej lirykach pojawiają się chwyty zaczerpnięte z poezji słowiarskiej - kolokwializmy i podsłuchane rozmowy przywodzące na myśl twórczość Białoszewskiego, zdekonstruowane frazeologizmy, które budzą skojarzenia z poezją nowofalową - zasadniczo jednak Wawiłow uprawia 
własną i oryginalną odmianę lingwizmu. Testuje możliwości języka nie tylko w konkretnych sytuacjach, ale przede wszystkim w odniesieniu do potrzeb jednostki, która próbuje wyrazić swoje odczucia, poglądy czy emocje. Perspektywa dziecka, którą poetka proponuje $\mathrm{w}$ większości wierszy, oraz konstrukcja podmiotu lirycznego jako samodzielnego i odrębnego - choć niewątpliwie dziecięcego - „ja” decydują o specyficznym charakterze jej twórczości oraz modulują mechanizmy poezji lingwistycznej.

W wierszu Kałużyści obok tytułowego neologizmu pojawiają się jeszcze inne, podobnie skonstruowane, nazwy wykonawców czynności („błociści”, „szyszkowiści”, „kocistki”) jednoznacznie wskazujące istotę podwórkowych dziecięcych zajęć, z perspektywy dorosłych nie zasługujących nawet na odrębne określenia, a w ujęciu kilkuletnich bohaterów lirycznych bardzo ważnych, nieomal nadających sens życiu. "Ja” liryczne nie ujawnia się, nie do dziecka też należy fraza opisująca kolejne zabawy, ale przyjęta w utworze skala wartości bez wątpienia jest odzwierciedleniem dziecięcego oglądu świata.

Rękawiczką i chusteczką dwóch błocistów chodnik czyści.

Obrzucają się szyszkami

bardzo dzielni szyszkowiści.

[Wawiłow 1993: 5]

Ciąg neologizmów wyliczonych w wierszu Wawiłow pozwala wyodrębnić z niebytu szereg zatrudnień, które inaczej pozostałyby niezauważone, funkcjonując poza językowym obrazem świata opisywanego według standardowych gramatycznych norm. Taplanie się w kałużach, zabawa w błocie, rzucanie szyszkami czy obłaskawianie podwórzowego kota - zajęcia pozornie błahe i pozbawione głębszego sensu - w utworze poetki nabierają wielkiego znaczenia właśnie dzięki zabiegom słowotwórczym, neologizmom utworzonym formantem właściwym dla nazw wykonawców czynności, przez analogię do takich rzeczowników jak „,traktorzyści”, „kombajniści”, „akordeoniści”, „basiści”, „sztangiści”, „florystki”, „flecistki”, „harfistki”, „florecistki” (choć też „kryminaliści” czy „krymina- 
listki”). Można więc domniemywać, że zajęcia podejmowane przez dzieci na podwórku to nie tylko - jak sugeruje wiersz - praca, ale również rodzaj sportu czy sztuki. Tak zbudowane neologizmy są nie tylko naśladowaniem dziecięcej inwencji słowotwórczej, ale podkreślają też wagę wymienionych zatrudnień, z dziecięcej perspektywy postrzeganych jako niezwykle istotne. Mikroświat podwórka przypomina w tym ujęciu rzeczywistość ukazaną w powieści produkcyjnej czy środowiskowej, gdzie w zamkniętej społeczności - na placu budowy, w fabryce czy wiejskiej spółdzielni - każdy wypełnia swoje zadania. Takim skojarzeniom sprzyjają nazwy (żywo obecne w języku peerelowskiej propagandy) określające pracowników, którzy obsługują maszyny rolnicze („kombajniści”, „traktorzystki”). Epitety „pracowici”, „bardzo dzielni” oraz potoczne słowo „robota”, pojawiające się we frazeologizmach "mieć pełne ręce roboty” $i$,wre robota", również nawiązują do stylistyki prozy opisującej robotnicze środowisko w duchu socjalistycznych idei. Być może próba dowartościowania dziecięcych zajęć wiąże się w wierszu Wawiłow z równoczesną, implikowaną deprecjacją socrealistycznych i propagandowych sposobów pisania.

O lingwistycznym charakterze utworu Kałużyści decyduje również szczególna gra rymów, w zaskakujący sposób spinających dość odległe klauzule. W poincie wiersza jeden z wersów zostaje pozbawiony ekwiwalencji rymowej:

Dwie kocistki pod laweczką cukierkami karmią kota...

Świątek, piątek czy niedziela, na podwórku wre robota!

[Wawiłow 1993: 5]

Poetka rezygnuje z mało oryginalnego, narzucającego się rymu „kota - sobota - robota”, wybiera dyskretne asonantyczne współbrzmienie „ławeczką - niedziela”. Tautologicznie rozbija frazeologizm „świątek, piątek” (wszak niedziela to właśnie dzień świąteczny, przeciwstawiony w przywołanym idiomie powszedniemu piątkowi). 
Nieoczywiste współbrzmienia, odległe rymy, onomatopeje i aliteracje są cechą charakterystyczną poezji Wawiłow. Nagromadzenie głosek „r” lub „k” w niektórych wersach przywołanego utworu przypomina ćwiczenia logopedyczne dla przedszkolaków, na przykład „kocistki [...] cukierkami karmią kota”, „na podwórku wre robota”. Częściej jednak poetka odwołuje się do specyfiki dziecięcej mowy i rezygnuje z zabiegów lingwistycznie edukacyjnych, aby z leksykalnych lapsusów czy pomysłów słowotwórczych kilkuletnich użytkowników języka wyłonić te, które są nacechowane poetycką wartością.. Słowotwórcze mechanizmy mowy dziecka, które twórczo uzupełnia ograniczony zasób słów, generując formy potencjalnie możliwe, lecz w systemie języka nieaktywne, wykorzystane zostają między innymi w utworze Jesienią [por. Banaszkiewicz 2011: 75]. Znudzony malec, zmuszony do siedzenia $\mathrm{w}$ domu z powodu jesiennej szarugi, wymyśla wiersz o konwencjonalnie baśniowym incipicie:

\section{ZA GÓRAMI}

\section{ZA LASAMI}

MIESZKAE KOTEK

ZAMIAUKANY.

[Wawiłow 1991: 62]

Zwroty i frazy obecne w języku dorosłych przefiltrowane przez świadomość kilkulatka często obnażają swoją słabość, okazują się puste, budzą zaskakujące dźwiękowe konotacje, przywołują nowe znaczenia w niespodziewanych paronomazjach. Dziecięca wyobraźnia przykłada słowa do rzeczywistości i nierzadko przystosowuje brzmienie niezrozumiałych określeń do sformułowań znanych, bezpiecznych oraz możliwych do zwizualizowania.

W wierszu Kwiat 26 wykorzystano dziecięcą pomyłkę językową - przedszkolak, który najwyraźniej nie zrozumiał, jak brzmi nazwa popularnego w latach 70. samochodu, przedmiotu powszechnego pożądania i zapewne ważnego tematu rozmów dorosłych, dopasowuje brzmienie zasłyszanych określeń do swojego zasobu słownictwa i prosi: 
Tatuś, kupisz mi samochód

Kwiat dwadzieścia sześć?

Tylko jeden mały Kwiacik,

Kwiat dwadzieścia sześć.

[Wawiłow 1991: 10]

Semantyczne neologizmy, analogiczne nie tylko do oficjalnej nazwy modelu fiata $126 \mathrm{p}$, ale też do potocznego określenia „mały fiacik”, wprowadzają polisemię i sprzyjają poetyckiej metamorfozie wymarzonego auta. Samochód jest „piękny, kolorowy”, „bombowy”, lecz nabiera nieco baśniowego charakteru - budzi skojarzenia z kwiatowym mieszkaniem Calineczki czy zaczarowaną karetą Kopciuszka. Lingwistyczny charakter wiersza Kwiat 26 podkreślają kolokwializmy - epitet „bombowy” oraz mianownik użyty w funkcji wołacza („tatuś”). Pojawiają się one także w innych utworach Wawiłow (np. wykrzyknienie „o rany Julek!”, Daktyle [Wawiłow 1993: 51]), służąc zazwyczaj uwiarygodnieniu dziecięcego idiolektu.

Elementy leksykalnej stylizacji - kolokwializmy czy neologizmy odzwierciedlające słowotwórczą świadomość kilkulatka, swobodnie budującego formy potencjalnie możliwe - często pojawiają się w pozycji rymowej, jak gdyby dziecko w charakterystyczny dla siebie sposób dopełniało współbrzmieniem frazę wypowiadaną przez dorosłego. Dziecięce dopowiedzenie rymowe bywa asemantyczne, wówczas wnosi tylko radość asonansu czy konsonansu, ale czasami stanowi szczególny, wartościujący komentarz do opowieści. Gdy małe wilczki (bohaterowie wiersza Wilki) po dniu wypełnionym zabawą wróciły do domu, musiały - podobnie jak zmęczone dzieci - wziąć wieczorną kąpiel. Powściągliwa jak dotąd antropomorfizacja zwierzaków, które biegały po lesie, bawiły się szyszkami, oglądały muchomory, „wywaliły się do wody”, „wlazły do mrowiska”, w ostatniej strofie staje się wyrazista i jednoznaczna:

Siedzą wilki, głośno wyją, bo im mamy 
głowy myją

szamponem - pamponem ...

[Wawiłow 1991: 35]

Żartobliwe, prześmiewcze określenie szamponu jest równocześnie wyrazem dystansu i negatywnych emocji właściwych raczej dzieciom niż młodym wilczkom. Taka pointa pozwala odczytać cały wiersz jako alegoryczną opowieść o dziecięcych zabawach „pośród leśnych chaszczy”, w konsekwencji których wcale nie zwierzaki „nosy mają podrapane, lapy mają upaprane” [Wawiłow 1991: 33]. Energiczne, ciekawskie, eksplorujące świat, pełne życiowej energii dzieci przypominają w swoim zachowaniu rozbawione wilczki. Przekraczają normy i zakazy, brudzą się, hałasują, rozrabiają, niekiedy przerażają swoich opiekunów. W poezji Wawiłow czynią to jednak w imię swojego - zdrowego oraz dobrze pojętego - rozwoju, zawsze bezpiecznie wracając pod opiekę mamy.

W innym wierszu (Marzenie) bohaterka liryczna - dziewczynka, która marzy o piesku - mówi:

Mógłby sobie być buldogiem -

karmiłabym go twarogiem.

[Wawiłow 1991: 41]

Dzięki oryginalnemu pomysłowi na podsuwanie psu białego sera (częstego składnika dziecięcego menu), dość stereotypowe pragnienie posiadania zwierzątka nabiera cech absurdu ewokowanego właśnie przez nacechowany komizmem rym.

Podobnie dzieje się w utworze Daktyle:

Gdzie się podziały

moje daktyle?

Może je zjadly

Straszne goryle?

[Wawiłow 1991: 51]

W tym przypadku komizm wynika nie tylko z zaskakującego rymu, ale i z wyliczeń, które pojawiają się w dalszej części wier- 
sza, służących rozładowaniu emocji. Utrata daktyli - smakołyku przyniesionego przez wujka - staje się mniej straszna w świetle absurdalnych przypuszczeń co do losu owoców.

W poszukiwaniu rymów oryginalnych i nietypowych Wawiłow posuwa się jednak znacznie dalej niż większość twórców wierszy lingwistycznych dla dzieci. Charakterystycznym elementem jej poetyki są rymy urwane, funkcjonujące analogicznie do obecnych między innymi w poezji dwudziestolecia międzywojennego rymów lamanych, jednak dopełnienie w tym przypadku nie zostaje przerzucone do kolejnego wersu, ale zniwelowane, jak gdyby połknięte przez zbyt szybko, emocjonalnie mówiące dziecko. Na przykład w wierszu Strasznie ważna rzecz czytamy:

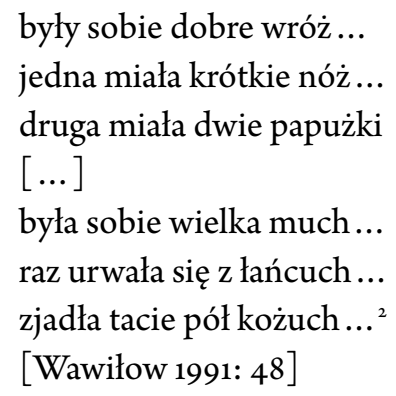

Wrażenie szczególnej stylizacji, naśladowania mowy dziecka szeptem powierzającego mamie wielkie tajemnice, potęguje fakt, że przywołanie pełnej formy słów umieszczonych w klauzuli w żaden sposób nie zaburzyłoby współbrzmienia. Ostatnia z wyliczonych w wierszu „strasznie ważnych rzeczy” wypowiedziana została pełnym głosem, wykrzyknieniami, z wyraźnie wyartykułowanymi klauzulami:

Mama, ja cię bardzo kocham!

Nie żartuję ani trochę!

Przecież jak się kogoś kocha, to jest ważna rzecz!

[Wawiłow 1991: 48] 
Emocjonalna deklaracja jest dużo bardziej istotna niż wcześniej zdradzane cicho tajemnice, wysnute z zakamarków dziecięcej wyobraźni, zostaje więc wypowiedziana głośno i wyraźnie. Nic tu się nie urywa w połowie, nie ginie w niesłyszalnym szepcie, nie zmusza do snucia domysłów. Zapewne takie wyznanie ma też ułagodzić mamę, zirytowaną dziecięcymi konfabulacjami, które odrywają ją od pracy („Mama, przestań zmiatać śmiecie!”, „Mama, nie pisz, tylko słuchaj!”). Warto podkreślić, że matczyne zatrudnienia są, jak to u Wawiłow, dwojakiego rodzaju - prace domowe przeplatają się z działalnością twórczą czy intelektualną.

W poetyckim świecie Wawiłow polszczyzna nie jest jedynym systemem, który służy komunikacji, wyrażeniu uczuć czy emocji. Bohaterowie liryczni jej utworów nawiązują empatyczny kontakt ze światem roślin, zwierząt czy nawet przedmiotów, ożywionych prawem personifikacji. Dziecięca wyobraźnia z rozmachem pozwala realizować postulaty komunikacji międzygatunkowej. Język zwierząt i roślin w tej poezji postrzega się jednak inaczej niż w liryce Wisławy Szymborskiej czy w dziecięcej poezji Juliana Przybosia [por. Balcerzan 1987: 196]. W wierszu byłego awangardzisty zatytułowanym Chowanka bohaterka liryczna - Uta, córeczka poety - protestuje przeciw przeintelektualizowanej, niezrozumiałej mowie ojca, porównując ją właśnie do języka zwierząt:

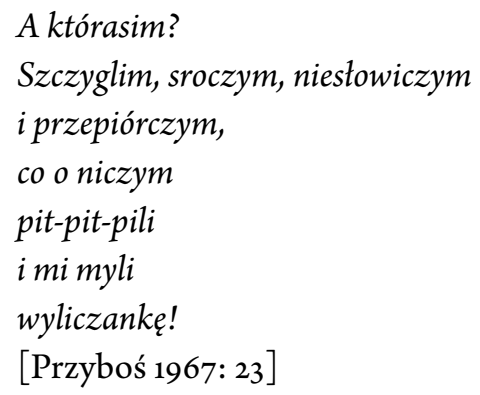

W poezji Wawiłow ewentualne niezrozumienie, szczególne bariery językowe nie przeszkadzają w szeroko pojętej komunikacji międzygatunkowej. Tak dzieje się choćby w wierszu Człowiek ze złotym parasolem, gdzie bohater liryczny i jego parasol wzajemnie 
wprawiają się w dobry humor. Parasol „śmieszne bajki plótł mu do ucha”, „człowiek mu odpowiadał” [Wawiłow 1991: 32]. Gadanina parasola, dzięki szeregowi aliteracji przypominająca jednostajny szum deszczu, nie umniejsza optymistycznego przesłania utworu:

I oboje byli weseli,

choć się wcale nie rozumieli,

bo ten człowiek gadał po polsku,

a parasol - po parasolsku ...

[Wawiłow 1991: 32]

Porozumienie z parasolem, zwierzętami, drzewami, a nawet pomnikami (na przykład w tekstach Czarny lew oraz Pomniki) w świecie dziecięcej wyobraźni jest zupełnie możliwe, podobnie jak rozmowy i zabawy z wyimaginowanymi stworami. Guskaj w wierszach Juliana Przybosia, Czupurek Anny Świrszczyńskiej czy tajemnicze Rupaki Wawiłow to istoty o zagadkowych nazwach, które przyjmują na siebie przewiny i emocje najmłodszych. Opowieść o Rupakach w naturalny sposób pozwala ująć i zwerbalizować dziecięce uczucia bez odwoływania się do abstrakcyjnych pojęć czy formul, na miarę możliwości językowych zarówno odbiorcy wirtualnego, jak i ,ja” lirycznego - zasypiającego malucha. Alicja Baluch, pisząc o kreacjach podobnych postaci w literaturze dziecięcej, podkreślała ich znaczenie dla rozwoju kompetencji społecznych, zwłaszcza umiejętności rozpoznawania oraz nazywania emocji bądź opisywania doświadczeń. Badaczka zauważyła:

Dzieci, podobnie jak ludzie pierwotni, nie umieją tworzyć zgrabnych uogólnień rzeczowych i dlatego muszą zmyślać postacie poetyckie i ich działania. Ujawniają się jednak w nich typowe wzorce zachowania i idealne portrety. Mają one na ogól charakter archetypowy, sięgają głębokich pragnień i tęsknot człowieka. [Baluch 1992: 17]

Rupaki z wiersza Wawiłow oswajają moment zasypiania oraz przejmują na siebie lęki małego człowieka. Wyliczenia, powtórze- 
nia i współbrzmienia obficie występujące w wierszu mają charakter uspokajający i wyciszający, działają jak kołysanka, łagodnie wprowadzając w świat sennych marzeń. Takie właśnie uwzględnienie potrzeb dziecięcej psychiki oraz uznanie takiego modelu percepcji za pełnowartościowy i równorzędny postrzeganiu dorosłych, choć pozbawiony odniesień do wiedzy o funkcjonowaniu świata, wyróżnia poezję Wawiłow spośród innych wierszy lingwistycznych. W omawianych utworach zabiegi lingwistycznie nie służą tylko zabawie, budowaniu współbrzmień, językowych zaskoczeń, polisemii czy komizmu. Kolejne chwyty artystyczne, powstałe w oparciu o operacje na systemie języka, są zazwyczaj elementem stylizacji (nawiązują do mechanizmów dziecięcej składni czy fleksji), wpisują się w rekonstrukcję dziecięcego systemu wartości, stanowią odzwierciedlenie młodzieńczej wyobraźni.

W typologii modeli nadawczo-odbiorczych wprowadzonych przez Baluch poezja Wawiłow reprezentuje odosobnienie „ja” lirycznego, separującego się od świata dorosłych, w którym spotyka się z brakiem zrozumienia i akceptacji swoich potrzeb³. Różnicę w sposobie postrzegania otaczającej rzeczywistości przez dziecko i dorosłego widać bardzo wyraźnie między innymi w wierszu Na wystawie:

Co tu jest namalowane?

Czy to człowiek? Czy to dzbanek?

A tu jakaś dziwna plama...

„Piękny obraz” - mówi mama.

[...]

Mamo, chodź tu! Mamo, zobacz!

To dopiero piękny obraz!

Kwitną kwiaty, słońce świeci,

Baluch ukazuje ewolucję literatury dziecięcej „od dydaktyzmu do artyzmu”, zmiany układu relacji osobowych i sytuacji komunikacyjnej, począwszy od poezji Jachowicza, w której dorosły kształtuje dziecko, przez przejawy coraz większego zrozumienia oraz szacunku dla twórczości dziecka, aż po międzypokoleniowy kontakt ( $w$ wierszach Juliana Przybosia), odosobnienie (właśnie w poezji Wawiłow) oraz porozumienie (spodziewane i oczekiwane w przyszłej twórczości) [por. Baluch 1987: 43; 1992: 87]. 
Na ławeczce siedzą dzieci...

Tylko taka brzydka rama ...

„To jest okno” - mówi mama.

[Wawiłow 1993: 21]

Opinia dziecka została zderzona z poglądami dorosłego, ale w tej konfrontacji nie uległa zachwianiu ani nie została podważona. Usamodzielnienie dziecięcego ,ja” lirycznego, uruchomienie perspektywy percepcji i recepcji właściwej kilkuletniemu dziecku, przyznanie mu prawa do indywidualnego postrzegania i oceniania, rezygnacja z umieszczenia „dorosłego” na wyższych poziomach nadawczych decydują między innymi o specyficznym charakterze poezji Wawiłow [por. Bula 2010/2011: 69].

Twórczość ta wpisuje się bowiem nie tylko $\mathrm{w}$ tradycję poezji lingwistycznej, ale też kontynuuje tradycję kobiecego wierszopisarstwa dla dzieci. Maria Konopnicka, Kazimiera Iłłakowiczówna, Hanna Łochocka, Joanna Pollakówna, Joanna Papuzińska, wspomniana już Świrszczyńska, a także wiele innych pisarek, wykorzystując tendencje i środki artystyczne współcześnie obowiązujące w literaturze, kreowały w swoich utworach postaci silnie zindywidualizowane, przekraczające schematy norm społecznych i poszukujące środków wyrazu dla świata jakże innego od wyobrażeń dorosłych. Obraz świata ukazany przez pryzmat percepcji dziecka lub z perspektywy braci mniejszych - upersonifikowanych zwierząt (jak wróbelek Elemelek z wierszowanej opowiastki Łochockiej) czy zmyślonych stworków (jak Czupurek z utworu Świrszczyńskiej) decyduje o odmienności tej poezji, w której dziecięce „ja” liryczne zyskuje coraz większą odrębność. Od innych wierszyków dla dzieci lirykę Wawiłow odróżnia też zaprojektowany w niej styl odbioru i model odbiorcy wirtualnego. Pierwszymi czytelnikami dziecięcych utworów poetki były jej własne dzieci - Natasza i Kostek pierwowzory wielu bohaterów lirycznych [por. Mucha 2005: 13]. Ich imiona pojawiają się w kolejnych tekstach. „Ja” liryczne tych utworów często się ujawnia w zaimkach osobowych oraz pierwszoosobowych formach czasownika poprzez zastosowanie męskiego lub żeńskiego rodzaju gramatycznego. Mimo tej różnorodności w poezji Wawiłow zaprojektowany zostaje feministyczny styl 
odbioru. Czytanie jako kobieta (według rozumienia Ewy Kraskowskiej) wymusza niejako uruchomienie perspektywy innego, pozostającego poza patriarchalną skalą wartości, obserwatora i uczestnika wydarzeń [por. Kraskowska 2007: 35]. Nie chodzi tu wyłącznie o opisanie świata z punktu widzenia dziecka, przez pryzmat jego odczuć i emocji w porządku patriarchatu uznawanych za błahe (jak zajęcia „kałużystów” i „kocistek” na podwórku w wierszu Kałużyści), choć już to byłoby wystarczającą przesłanką do odczytania twórczości Wawiłow w ujęciu krytyki feministycznej. Istotna wydaje się też kreacja bohaterek dziewczęcych, którym w żaden sposób nie grozi niewidzialność, stopienie się z tłem, dopasowanie do narzuconych reguł, idealna grzeczność determinująca przezroczystość. Dziewczynki z poezji Wawiłow wiedzą, czego chcą, są zdecydowane, bez wahania wyrażają swoje opinie i emocje, dążą do wyznaczonych celów, potrafią podejmować decyzje oraz bywają niegrzeczne (to znaczy niedopasowane do obowiązujących opresyjnych norm, narzucanych dzieciom bezkompromisowo i odgórnie).

Opresyjny charakter tych norm jest wielokrotnie sygnalizowany poprzez aluzje do stosowania przemocy fizycznej wobec dzieci, wymierzania kar cielesnych, wpisane w językowy obraz świata. Bohater wiersza Kopareczka przewiduje, że zostanie ukarany za dziurę w dywanie, który podarł się podczas zabawy:

Po dywanie pojeździmy, posyczymy, powarczymy, wykopiemy w ziemi dziurę, dostaniemy za to w skórę. [Wawiłow 1993: 11]

Podobnie w Dziwnej bajeczce rodzice, którzy odnaleźli zagubionego synka:

troszeczkę się pośmiali, troszeczkę popłakali, troszeczkę mu przylali a może nie troszeczkę.

[Wawiłow 1993: 18] 
W jeszcze innym utworze - Moja siostra królewna - młodszy brat nie odczuwa szczególnej skruchy, gdy zdarzy mu się uderzyć siostrę:

Jak ją rąbnę niechcący,

zaraz leci do mamy,

ale to jest nieważne,

bo i tak się kochamy.

[Wawilow 1991: 65]

Lingwizm Wawiłow staje się więc wyrazem głosu innego, próbą wprowadzenia idiolektu poetyckiego, który będzie współgrał z odczytaniem przekraczającym patriarchalną skalę wartości i z wpisanym w tę twórczość projektem poziomów nadawczo-odbiorczych. To wołanie dziecka, które musi zostać usłyszane oraz zauważone, aby mogło bezpiecznie budować swoją tożsamość i poczucie własnej wartości. Poezja Wawiłow powołuje do istnienia rożne sytuacje i związane z nimi emocje, zanim wydarzą się naprawdę, „zrealnieją”, nabiorą nieodwracalnej mocy. Być może oswojone przez poezję, opowiedziane językiem stylizowanym na mowę dziecka, przestaną być groźne i będzie można się z nimi pogodzić tak, jak udaje się to bohaterce Smutnego wiersza, która rozpoznaje swoje emocje i odważnie o nich opowiada:

Dzisiaj jestem smutna

jak ptak.

Dzisiaj jestem smutna

jak deszcz.

[Wawiłow 1993: 34]

\section{Bibliografia}

Balcerzan Edward (1998), Poezja polska w latach 1939-1968, wSiP, Warszawa.

Baluch Alicja (1987), Dziecko i świat przedstawiony czyli tajemnice dziecięcej lektury, Wacław Bagiński i Synowie, Warszawa.

Baluch Alicja (1992), Archetypy literatury dziecięcej, Wydawnictwo

Naukowe wsp, Kraków. 
Banaszkiewicz Agnieszka (2011), Fleksja werbalna w mowie dzieci pięcioletnich, Wydawnictwo UMCs, Lublin.

Bula Danuta (2010/2011), Dziecko zaprasza dorostego do swojego świata, czyli o poezji Danuty Wawitow, „Język Polski w Szkole”, nr 2, s. 66-71.

Cieślikowski Jerzy (1967), Wielka zabawa, Zakład Narodowy im. Ossolińskich, Wrocław.

Czukowskij Korniej (1962), Od dwóch do pięciu, przeł. Wiktor Woroszylski, Nasza Księgarnia, Warszawa.

Kraskowska Ewa (2007), Czytelnik jako kobieta. Wokół literatury i teorii, Wydawnictwo Naukowe UAM, Poznań.

Mucha Danuta (2005), Danuta Wawiłow (1942-1999) - życie i twórczość, Naukowe Wydawnictwo Piotrkowskie, Piotrków.

Przyboś Julian, Przyboś Uta (1967), Wiersze i obrazki, Czytelnik, Warszawa.

Smuszkiewicz Antoni (2015), Literatura dla dzieci, Wydawnictwo Naukowe UAM, Poznań.

Szóstak Anna (2003), Od modernizmu do lingwizmu: o przemianach w twórczości Jana Brzechwy, TAiwpN Universitas, Kraków.

Wawiłow Danuta (1991), Dzieci w lesie, Ludowa Spółdzielnia Wydawnicza, Warszawa.

Wawiłow Danuta (1993), Wierszykarnia, Nasza Księgarnia, Warszawa.

Agnieszka Kwiatkowska

"And here we are together, making up tales and tall stories". Linguism in the poetry of Danuta Wawilow

Danuta Wawilow's poems for children were created in the second half of the 2oth century. The poems classify as the language poetry, employing in the compositions the mechanisms and figures of speech characteristic of this aesthetic current. The poet uses stylization, she reconstructs the creative attitude to language typical of kindergarteners, which is based on experimentation and abounding in similar-sounding words. Wawiłow implements the particularly strongly individualized variation of linguism. She tests the language potential with regards to the needs of an individual a child who attempts to express their feelings, thoughts, and emotions. Wawiłow's poetry is not only focused on the language, but also explores the subjectivism of the lyrical subject and new ways of its expression.

Keywords: linguism; linguistic poetry; poems for children; Wawiłow; the reader as a woman. 
Agnieszka Kwiatkowska - profesorka w Zakładzie Literatury xx Wieku, Teorii Literatury i Sztuki Przekładu UAM, badaczka poezji współczesnej, autorka monografii poświęconej twórczości Juliana Przybosia oraz licznych publikacji dotyczących pisarstwa kobiet. Obecnie zajmuje się m.in. poezją dla dzieci, zwłaszcza powstającą $\mathrm{w}$ kręgu awangardowym oraz pisaną przez kobiety. 
